http://dx.doi.org/10.12775/RT.2019.001

Jarosław Kłaczkow*

\title{
Polskie Pomorze czy Prusy Zachodnie? \\ Kwestia przynależności państwowej regionu w latach 1918-1920
}

Polish Pomerania or West Prussia?

The issue of the political belonging of the region in the years 1918-1920

\section{Polnisches Pommern oder Westpreußen?}

Die Frage der staatlichen Zugehörigkeit der Region in den Jahren 1918-1920

Streszczenie. Obszar Pomorza Gdańskiego i powiązanych z nim historycznie ziem chełmińskiej, michałowskiej i lubawskiej funkcjonował w Rzeszy Niemieckiej jako obszar administracyjny Prusy Zachodnie. Przez wieki przenikały się tu wpływy polskie i niemieckie, a teren przechodził z rąk do rąk. Pierwotnie należący do Królestwa Polskiego, w XIII i XIV w. zajęty przez zakon krzyżacki, od 1466 do 1772 r. ponownie w ramach Polski, przeszedł następnie w wyniku rozbiorów do państwa pruskiego. W 1914 r. u progu wybuchu

\footnotetext{
${ }^{*}$ Historyk, profesor nauk humanistycznych, pracownik Uniwersytetu Mikołaja Kopernika w Toruniu, kierownik Katedry Historii XIX-XX Wieku i Historii Najnowszej w Instytucie Historii i Archiwistyki UMK. W latach 2006-2015 prezes toruńskiego oddziału Polskiego Towarzystwa Historycznego. Od września 2015 r. członek Zarządu Głównego Polskiego Towarzystwa Historycznego i Komitetu Nauk Historycznych PAN. Zainteresowania badawcze koncentruje na historii społeczno-politycznej Polski XX w. ze szczególnym uwzględnieniem spraw wyznaniowych i dziejów miast (współautor monografii Kwidzyna, Golubia-Dobrzynia). Autor 12 monografii, 3 podręczników szkolnych (współautor), redaktor i współredaktor 23 prac zbiorowych. ORCID: 0000-0002-0715-2264
} 
Wielkiej Wojny wydawało się, że tę kilkuwiekową rywalizację wygrała strona niemiecka. Tendencje demograficzne były bowiem bardziej korzystne dla Niemców. Według oficjalnych danych pochodzących ze spisu ludności z $1910 \mathrm{r}$. ówczesną prowincję Prusy Zachodnie zamieszkiwało 65\% ludności niemieckiej i 35\% polskiej. Cztery lata Wielkiej Wojny odmieniły tę sytuację. W listopadzie 1918 r. Niemcy przegrały wojnę, a na arenę międzynarodowych rokowań powróciła sprawa niepodległości Polski i jej powrotu nad Bałtyk. Miejscowe koła polskie podjęły również działania mające na celu zorganizowanie lokalnych struktur polskich. Tak powstał Podkomisariat Naczelnej Rady Ludowej z siedzibą w Gdańsku, a w każdym powiecie lokalne Rady Ludowe. Powstawały również struktury konspiracyjne, $\mathrm{w}$ tym przede wszystkim Organizacja Wojskowa Pomorza. Jej struktury były szczególnie aktywne w Borach Tucholskich oraz na terenie ziemi chełmińskiej. O ostatecznym kształcie granic i przynależności spornych ziem zadecydował traktat wersalski podpisany w dniu 28 czerwca 1919 r. Na jego mocy 62\% terenu prowincji Prusy Zachodnie zostało przyznane Polsce. Poza Polską pozostała jednak stolica ziemi pomorskiej - Gdańsk, który przez kolejne pokolenie wiódł życie wolnego miasta. To zadecydowało, że nową stolicą polskiego Pomorza został Toruń, który powrócił do Polski 18 stycznia 1920 r.

Abstract. The area of Gdańsk Pomerania and the historically related lands of Chełmno, Michałów and Lubawa functioned in the Second Reich as the administrative area of West Prussia. For centuries, Polish and German influences had affected the territory, which tended to change its owners. Originally, the territory belonged to the Kingdom of Poland; in the $13^{\text {th }}$ and $14^{\text {th }}$ centuries it was occupied by the Teutonic Order, while from 1466 to 1772 it remained again under the authority of Poland only to become part of the Prussian state as a result of partitions. In 1914, at the beginning of the outbreak of the Great War, it seemed that the German party had won this competition lasting for several centuries. Demographic trends were more favorable for the Germans. According to the official data of the 1910 census, the then province of West Prussia was inhabited by $65 \%$ of the German and $35 \%$ of the Polish population. Four years of the Great War changed this situation. In November 1918, Germany lost the war, and the issue of Poland's independence and its return to the Baltic came back to the arena of international negotiations. Local Polish circles also took actions to organize local Polish structures. This is how the Subcommittee of the Supreme People's Council based in Gdańsk was established; what is more, local People's Councils were set up in each county. Underground structures were also emerging, including above all the Military 
Organization of Pomerania. Its structures were particularly active in the Tuchola Forest and in the Chełmno region. The final shape of the borders and the political belonging of the disputed lands was decided by the Versailles Treaty signed on 28 June 1919. Upon the strength of the Versailles Treaty, 62\% of the area of the province of West Prussia was granted to Poland. However, the capital of Pomerania - Gdańsk, which was declared the free city, remained outside Poland. All this influenced the fact that Torun, which returned to Poland on 18 January 1920, became the new capital of Polish Pomerania.

Zusammenfassung. Das Gebiet des Danziger Pommerns und der mit ihm historisch verbundenen Länder von Kulm, Michelau und Löbau bildete im Deutschen Kaiserreich das Verwaltungsgebiet Westpreußen. Jahrhundertelang durchdrangen sich auf diesem Gebiet polnische und deutsche Einflüsse und das Gebiet wechselte ständig den Besitzer. Ursprünglich gehörte es zum Königreich Polen, im 13. und 14. Jahrhundert wurde es vom Deutschen Orden besetzt, 1466-1772 war es erneut bei Polen und kam danach infolge der Teilungen an den preußischen Staat. 1914, vor Beginn des 1. Weltkriegs hatte es den Anschein, als sei diese jahrhundertelange Rivalität von der deutschen Seite gewonnen worden. Denn die demografischen Tendenzen entwickelten sich zugunsten der Deutschen. Nach den offiziellen Angaben aus der Volkszählung von 1910 wohnte in der damaligen Provinz Westpreußen 65\% deutsche und 35\% polnische Bevölkerung. Die vier Jahre des Großen Kriegs veränderten diese Situation. Im November 1918 verlor Deutschland den Krieg und die Frage der Unabhängigkeit Polens und seiner Rückkehr an die Ostsee kehrte auf die Tagesordnung der internationalen Verhandlungen zurück. Örtliche polnische Kreise wurden aktiv, um lokale polnische Strukturen zu organisieren. Auf diese Weise entstanden das Unterkommissariat des Obersten Volksrats mit Sitz in Danzig sowie lokale Volksräte in jedem Landkreis. Ebenso entstanden konspirative Strukturen, darunter vor allem die Pommersche Militärorganisation. Ihre Strukturen waren vor allem in der Tucheler Heide und auf dem Gebiet des Kulmer Landes aktiv. Über den endgültigen Verlauf der Grenzen und die Zugehörigkeit strittiger Gebiete entschied der Versailler Vertrag, der am 28. Juni 1919 unterschrieben wurde. Nach seinen Bestimmungen wurden $62 \%$ des Gebiets der Provinz Westpreußen Polen zugesprochen. Außerhalb von Polen blieb jedoch die Hauptstadt von Pommern, Danzig, das während der folgenden Generation als Freie Stadt existierte. Das führte dazu, dass zur neuen Hauptstadt des polnischen Pommerns Thorn wurde, das am 18. Januar 1920 zu Polen zurückkehrte. 
Słowa kluczowe: Pomorze Gdańskie, ziemie: chełmińska, michałowska, lubawska, Prusy Zachodnie, Podkomisariat Naczelnej Rady Ludowej, Rady Ludowe, Organizacja Wojskowa Pomorza

Keywords: Gdańsk Pomerania, lands of Chełmno, Michałów, Lubawa, West Prussia, Subcommittee of the Supreme People's Council, People's Councils, Military Organization of Pomerania

Schlüsselwörter: Danziger Pommern, Kulmer Land, Michelauer Land, Land Löbau, Westpreußen, Unterkommissariat des Obersten Volksrats, Volksräte, Pommersche Militärorganisation

Wybuch I wojny światowej (wówczas nazywanej Wielką Wojną) był dla wszystkich zaskoczeniem. Spodziewano się wprawdzie, że ona nastąpi, znawcy polityki wyznaczali nawet datę jej rozpoczęcia na rok 1917. W momencie, w którym wybuchła, nikt nie zdawał sobie jednak sprawy, jakie będą jej konsekwencje. Wczesnym latem 1914 r. porządek światowy wydawał się bowiem niezachwiany. Europa znajdowała się u szczytu swojej potęgi i znaczenia. Do państw europejskich należał prawie cały kontynent afrykański i część Azji. Europejska kultura, zwłaszcza francuska, nadawała ton ówczesnemu światu, a imperium brytyjskie, obejmujące blisko $37 \mathrm{mln} \mathrm{km}^{2}$, stało się największym w historii ludzkości.

Na Starym Kontynencie panowały również od wielu stuleci te same dynastie, a sieć wzajemnych powiązań rodzinnych uosabiały bliźniaczo podobne do siebie postacie władcy Zjednoczonego Królestwa Wielkiej Brytanii i Irlandii króla Jerzego V z dynastii Sachsen-Coburg Gotha i cara Rosji Mikołaja II Romanowa. W Niemczech panował porywczy i megalomański Wilhelm II Hohenzollern, a w AustroWęgrzech sędziwy, obdarzony ogromnym autorytetem i szacunkiem cesarz Franciszek Józef I Habsburg.

To jednak rozsadzana waśniami narodowościowymi monarchia habsburska miała się stać tym elementem europejskiej układanki politycznej, która uruchomi lawinę wydarzeń mających doprowadzić do upadku belle époque. 
Tereny Pomorza Gdańskiego, zwanego również Wschodnim, Nadwiślańskim, Prusami Królewskimi, a w terminologii niemieckiej Prusami Zachodnimi, były obszarem szczególnym i ważnym. Od czasów średniowiecza ścierały się tam wpływy polskie i niemieckie, a obszar przechodził z rąk do rąk. Pierwotnie związany z piastowską monarchią polską, w 1308 r. został zajęty przez zakon krzyżacki i aż do 1466 r. pozostawał w jego władaniu. Następnie, przez kolejne 300 lat pod nazwą Prusy Królewskie był częścią państwa polsko-litewskiego. W 1772 i 1793 r., tj. w czasie I i II rozbioru, włączono go w obręb państwa pruskiego. Z krótkim epizodem Księstwa Warszawskiego (18071815), gdy odłączono od Prus ziemie chełmińską, michałowską i lubawską, tereny pomorskie pozostawały pod władzą niemiecką aż do stycznia $1920 \mathrm{r}$.

Tak jak zmieniała się przynależność terytorialna, tak samo ulegał modyfikacjom skład etniczny. Wśród Słowian, dominujących w okresie pierwszych wieków drugiego tysiąclecia na tych terenach, zaczęła się osiedlać, wraz z postępującym rozwojem gospodarczym, ludność pochodząca $\mathrm{z}$ różnych krajów niemieckich. W okresie nowożytnym, szczególnie na tereny ziem chełmińskiej, michałowskiej i lubawskiej, napływała również ludność z sąsiedniego Mazowsza i ziemi dobrzyńskiej. Przybywali także uchodźcy polityczni i religijni z zachodniej Europy, przede wszystkim niderlandzcy menonici, jak i grupy pochodzące z Wysp Brytyjskich czy hugenoci z Francji. Z biegiem czasu te $\mathrm{i}$ inne grupy polonizowały się lub germanizowały, wstępując w sposób naturalny do jednej $\mathrm{z}$ dwóch dominujących na tym terenie nacji. $\mathrm{Z}$ tego tygla językowego i religijnego tworzył się podstawowy i w miarę porównywalny na początku XX w. pod względem ilościowym kościec pomorski: polsko- lub niemieckojęzyczny.

U progu Wielkiej Wojny tendencje demograficzne były jednak bardziej korzystne dla strony niemieckiej. Według oficjalnych danych pochodzących z ostatniego spisu ludności z 1910 r. ówczesną prowincję Prusy Zachodnie zamieszkiwało 65\% ludności niemieckiej i 35\% polskiej ${ }^{1}$. Ludność polska dominowała na terenach Kaszub, Kociewia,

\footnotetext{
${ }^{1}$ L. Belzyt, Sprachliche Minderheiten im preußischen Staat 1815-1914, Marburg
} 1998, s. 17. 
ziemiach chełmińskiej, michałowskiej i lubawskiej. Na tym ostatnim obszarze stanowiła blisko $80 \%$. Konsekwentna polityka germanizacyjna i naturalne procesy asymilacyjne jednak postępowały. W związku z takim stanem rzeczy ludność niemiecka była coraz bardziej pewna siebie, mając w pamięci słowa swoich przywódców Bismarcka i Wilhelma II, że Niemcy boją się tylko Boga, a poza tym nikogo innego na świecie. Była ona także świadkiem, jak jej państwo w ciągu dwóch pokoleń stało się najpotężniejszym mocarstwem w Europie i drugą, po USA, gospodarką świata. Natomiast aktywny, bardzo patriotyczny, ale stopniowo kurczący się krąg ludności polskiej patrzył z niepokojem w przyszłość. Z niemieckiej strony słychać było triumfalny hymn „Westpreussenlied" ze słowami Paula Felske i muzyką Hugo Hartmanna, zaczynający się od słów: „Westpreussen, mein lieb’ Heimatland. Wie bist du wunderschön". Z polskiej zaś uparte, ale coraz bardziej diasporalne akcentowanie słowiańskości tego terenu, m.in. w „Marszu Kaszubskim" autorstwa Hieronima Derdowskiego. Padały tam wyraźne i dobitne słowa: „Tam gdzie Wisła od Krakowa w polskie morze płynie, Polska wiara, polska mowa nigdy nie zaginie". Poza Kaszubami dominowały klasyczne polskie pieśni patriotyczne, a „Mazurka Dąbrowskiego”, „Rotę” czy „Boże coś Polskę” znało każde polskie dziecko. Niemcy powtarzali także często pieśń Ernsta Moritza Arndta: „Wo ist des Deutschen Vaterland”, w której padały słowa: „So weit die deutsche Zunge klingt”, a Polacy w tej samej narracji głosili: „Dokąd język polski sięga, tak daleko polska rozciąga się Ojczyzna"2.

Ta walka o rząd dusz nie była już jednak u progu 1914 r. tak wyrównana, a strona niemiecka stawała się coraz bardziej dominującą. Porównywalne proporcje występowały jedynie w obszarze wyznaniowym, gdzie odsetek katolików i ewangelików wynosił odpowiednio, według spisu z 1910 r., 52\% i 46\%, co z kolei świadczyło o postępującej germanizacji ludności wyznania katolickiego.

Wielka Wojna nie zmieniła statystyki, ale dokonała radykalnych zmian w świadomości. Gdy wojska wyruszały na front, miejscowi Polacy liczyli się z szybkim triumfem Niemiec i przyspieszeniem ger-

${ }^{2}$ R. Wapiński, Polska i małe ojczyzny Polaków, Wrocław-Warszawa-Kraków 1994, s. 125 . 
manizacji. Nie sprawdziła się jednakże kolejna „złota myśl” Wilhelma II, który w sierpniu 1914 r. miał powiedzieć do maszerujących na śmierć żołnierzy: „Wrócicie zanim spadną liście z drzew”. Faktycznie, liście opadły z drzew, przyszła zima, ale żołnierze na tej wojnie pozostali i masowo ginęli w kolejnych latach. Dość wspomnieć, że zginęło wówczas 38 milionów osób, a 8 kolejnych milionów uznano za zaginione. Pozostała w wojujących państwach ludność cywilna z coraz większym trudem znosiła uciążliwości wojny, a wyraźną cechą schyłku konfliktu był powszechny głód. To musiało wywołać wrzenie społeczne i zachwianie dotychczasowego ładu społecznego i ustrojowego. $\mathrm{Na}$ fali załamywania się systemu monarchicznego i postępującego upadku państw zaborczych rosły nadzieje Polaków na odzyskanie własnego państwa. Jesienią $1918 \mathrm{r}$. stało się to faktem.

Dnia 11 listopada $1918 \mathrm{r}$. Niemcy poprosiły o rozejm na froncie zachodnim. W chwili jego zawierania walczyły już praktycznie same, gdyż Austro-Węgry rozpadły się i przestały istnieć de facto jako państwo już pod koniec października 1918 r. W samych Niemczech 9 listopada wybuchła rewolucja, która doprowadziła do upadku monarchii Hohenzollernów i innych dynastii w pozostałych krajach Rzeszy oraz spowodowała pojawienie się rad robotniczo-żołnierskich. Wielosetletni niemiecki system monarchiczny przeszedł do historii. Jego miejsce zajęła republika. W całym kraju powstawały m.in. rady robotniczożołnierskie. 8 listopada zawiązano taką w Tucholi, uzyskując poparcie miejscowego społeczeństwa oraz przebywających na tym terenie jeńców wojennych z krajów alianckich. Dzień później rada powstała w Toruniu, co skutkowało m.in. rozbrojeniem miejscowej żandarmerii, opanowaniem więzienia przy ulicy Fosa Staromiejska i uwolnieniem aresztowanych. W dniach 10-11 listopada uformowały się rady robotniczo-żołnierskie w Bydgoszczy, Chełmży, Chełmnie, Brodnicy, Chojnicach i Świeciu ${ }^{3}$. W Orłowie (powiat wąbrzeski) symbolicznym sygnałem zmiany władzy stało się usunięcie cesarskiego czarnego orła ze skrzynki pocztowej. Zniknęły trójkolorowe, biało-czerwono-czarne flagi pruskie, a nad budynkami publicznymi zaczęły powiewać czer-

${ }^{3}$ J. Wojtowicz, Czasy zaboru, [w:] Województwo bydgoskie. Krajobraz. Dzieje. Kultura. Gospodarka, Poznań 1967, s. 150-151. 
wone sztandary. I tu jednak też zdarzały się wyjątki, np. w Toruniu w okresie rewolucji listopadowej na wieży ratuszowej powiewała także flaga polska ${ }^{4}$. Generalnie rady pozostawały pod wpływami politycznymi Socjaldemokratycznej Partii Niemiec (SPD), niemniej jednak część jej członków sympatyzowała z komunizującym Związkiem Spartakusa, jednym z jego działaczy był Artur Raube pochodzący z Torunia. Ich działalność można było także zauważyć m.in. w Bydgoszczy, Grudziądzu, Tucholi czy Brodnicy ${ }^{5}$. Rady robotniczo-żołnierskie starały się wchodzić w kompetencje dotychczasowych władz miejskich, powiatowych czy prowincji, co prowadziło w praktyce do dwuwładzy. Początkowo większość w radach mieli Niemcy, z biegiem czasu w ich składzie zaczęli się również pojawiać Polacy. Tak było np. w Chełmży, gdzie w gronie członków rady dominowali Polacy ${ }^{6}$.

Dnia 11 listopada Polska odzyskała niepodległość. W Warszawie przebywał już Józef Piłsudski, który tego dnia przejął z rąk Rady Regencyjnej władzę wojskową, a trzy dni później, jako Naczelny Dowódca, również cywilną. 11 listopada 1918 r. na granicy dawnego Królestwa Polskiego z zaborem pruskim pojawiły się polskie posterunki graniczne. Mieszkający na terenie zaboru pruskiego Polacy musieli jednak poczekać jeszcze blisko 1,5 roku na powrót do ojczyzny.

Z punktu widzenia Polaków Pomorze Gdańskie było bardzo ważnym regionem, gdyż otwierało im dostęp do Bałtyku, a w konsekwencji „okno” na świat. Z kolei dla Niemców najistotniejsze było to, że był to teren łączący Prusy Wschodnie z resztą ziem niemieckich. Po utracie Pomorza Gdańskiego obszar Niemiec uległby podziałowi na dwie części. Trudno więc o większy ładunek własnych ambicji i interesów. Nie było przy tym jakiejkolwiek możliwości usatysfakcjonowania obu stron konfliktu.

Polacy zamieszkujący Prusy Zachodnie znajdowali się w gorszej sytuacji niż ich poznańscy sąsiedzi. Tereny Pomorza graniczyły bo-

\footnotetext{
${ }^{4}$ P. Kosiński, Prusy Zachodnie 1914 - Pomorze 1920. Ludność regionu wobec przemian politycznych okresu I wojny światowej, Warszawa 2002, s. 181.

${ }^{5}$ J. Wojtowicz, op. cit., s. 152.

${ }^{6}$ M. Wojciechowski, Dzieje Chetmży w latach 1914-1920, [w:] Dzieje Chetmży, red. M. Wojciechowski, Chełmża 1994, s. 154.
} 
wiem (w większości) z niemieckimi pod względem etnicznym prowincjami: Pommern (Pomorze) i Ostpreussen (Prusy Wschodnie). Na północy było morze i tylko na południu prowincja Prusy Zachodnie przylegała do odrodzonej Polski. Ponadto na jej terenie znajdowały się potężne twierdze pruskie: w Toruniu i Grudziądzu. Silne garnizony stacjonowały również w Chełmnie, Tczewie czy Malborku. Co było także istotne, fala rewolucyjna w wojsku niemieckim stopniowo opadała, a wszystkie ugrupowania polityczne, w tym rady robotniczożołnierskie, stały twardo i nieustępliwie na gruncie niepodzielności terytorium pokonanych Niemiec. Coraz więcej zwolenników znajdowała także w społeczeństwie niemieckim teza o „,ciosie nożem w plecy" (Dolchstoßlegende), który rzekomo zwycięskiej armii zadała czerwono-czarno-żółta międzynarodówka. Tendencje nacjonalistyczne w społeczeństwie niemieckim nie opadły, a nawet nastąpił ich wzrost. Objęły one również niemieckich mieszkańców Pomorza i polscy działacze narodowi musieli mieć to na uwadze.

Wśród miejscowych Polaków przeważał pogląd, że większych szans na zryw powstańczy nie ma. Oczekiwano natomiast na werdykt paryskiej konferencji pokojowej. Postawiono więc przede wszystkim na rozbudowę własnej reprezentacji politycznej. Jesienią 1918 r. w każdym powiecie powstały polskie rady ludowe podporządkowane $\mathrm{Na}-$ czelnej Radzie Ludowej w Poznaniu. Odgrywały one rolę faktycznych reprezentantów polskiej społeczności zaboru pruskiego i politycznie związane były $\mathrm{z}$ dominującą $\mathrm{w}$ zaborze pruskim narodową demokracją. I tak np. w Chełmnie Powiatowa Rada Ludowa powstała 24 listopada 1918 r. W jej skład weszli: ks. Zygmunt Rogala, Ottomar Krefft, Jan Odrowski, Jakub Arczyński, Paweł Ossowski oraz nieznani z imienia ks. Lipski, Mamel, Kozakiewicz i Bukowski ${ }^{7}$. Z kolei 12 grudnia 1918 r. na członków rady na powiat toruński z siedzibą w Chełmży zostali wybrani: Adam Czarliński z Zakrzewka, Stanisław Łukomski, ks. Józef Wrycza, Stanisław Pilatowski, Maks Grabowski.

Jawną organizacją polską pozostawał także, powołany 13 grudnia 1918 r., Podkomisariat Naczelnej Rady Ludowej z siedzibą w Gdań-

${ }^{7}$ Dzieje Chetmna. Zarys monograficzny, red. M. Biskup, Warszawa-Poznań-Toruń 1987, s. 272. 
sku. Kierował nim Stefan Łaszewski, a w kierownictwie zasiadał również pochodzący z Gdańska Józef Wybicki. W kręgu najbliższych współpracowników Łaszewskiego znaleźli się: Franciszek Kręcki, prawnik Roman Wawrowski ze Świecia, Mieczysław Marchlewski, Stanisław hr. Sierakowski, Brunon Gabryelewicz, Józef Głowacki, Lange, Szczepan Gracz, Paweł Dykta i ks. Bolesław Makowski ${ }^{8}$.

Nie zaniechano jednak konspiracyjnych przygotowań do ewentualnych działań zbrojnych. I tak w listopadzie $1918 \mathrm{r}$. na terenie powiatu toruńskiego powstała Straż Bezpieczeństwa z Kazimierzem Siudowskim na czele, a następnie, po jej likwidacji w grudniu 1918 r., Straż Ludowa, Towarzystwo Wojackie „Jedność”, Towarzystwo Młodzieży Polskiej i Towarzystwo Gimnastyczne „Sokół” (tylko w Toruniu ta ostatnia organizacja liczyła w marcu 1919 r. 520 członków) ${ }^{9}$. Prawdopodobnie weszły one w skład większej, konspiracyjnej struktury pod nazwą Organizacja Wojskowa Pomorza (OWP). Powstała ona na przełomie 1918/1919 r., a jej przywódcą został dr Franciszek Kręcki z Gdańska. Jego współpracownikami byli ponadto: Józef Wybicki, Oswald Potocki, Leon Czarliński. Miejscem dowództwa organizacji był gmach Podkomisariatu Naczelnej Rady Ludowej w Gdańsku.

Organizacja Wojskowa Pomorza działała w czterech okręgach. Pierwszy obejmował powiaty: chełmiński, toruński i wąbrzeski. Jego komendantem został Leon Czarliński, a po nim Wincenty RawiczDembiński. Drugi okręg to powiaty: brodnicki, grudziądzki, kwidzyński, lubawski, świecki oraz Warmia i Mazury. Komendę nad nim sprawował Józef Goga. Trzeci i czwarty obejmowały Kaszuby i Kociewie, tj. powiaty: chojnicki, kartuski, kościerski, pucki, starogardzki, tczewski, tucholski, wejherowski, złotowski.

Organizacja Wojskowa Pomorza pozostała strukturą konspiracyjną, osadzoną głównie na terenach miejskich, m.in. w Grudziądzu, Tucholi, Świeciu czy Chełmży. Największe poparcie miała w powiatach kaszubskich i kociewskich (Kartuzy, Kościerzyna, Tczew) ${ }^{10}$. Głównym miej-

\footnotetext{
${ }^{8}$ M. Szurło-Gorzelak, Pomorski Urząd Wojewódzki. Jego powstanie, rozwój i chwila obecna, [w:] Księga pamiątkowa dziesięciolecia Pomorza, Toruń 1930, s. 283.

${ }^{9}$ M. Wojciechowski, Powrót Pomorza do Polski 1918-1920, Warszawa-PoznańToruń 1981, s. 80-83.

${ }^{10}$ Ibid., s. 84,86 .
} 
scem tworzenia się partyzantki tej organizacji były Bory Tucholskie, a tamtejszymi oddziałami dowodzili m.in. Wincenty Szpica, Franciszek Kleinschmidt czy bracia Gnacińscy ${ }^{11}$. Na ziemi chełmińskiej działaczami Organizacji Wojskowej Pomorza byli na pewno: ks. Jan Wrycza, Stanisław Michalski i Bolesław Dzięgielewski ${ }^{12}$.

Przygotowywanie się do ewentualnego zbrojnego wystąpienia nie było przypadkowe. Pod koniec 1918 r. ważyły się decyzje dotyczące przetransportowania na ziemie polskie Armii Polskiej z Francji (tzw. Błękitnej Armii dowodzonej od października 1918 r. przez gen. Józefa Hallera). Według pierwotnych planów alianckich armia ta miała przybyć do Polski drogą morską, wylądować w Gdańsku i przemieszczać się dalej w kierunku centralnych ziem polskich. Informacje te nie wymagały specjalnej wyobraźni, aby unaocznić Niemcom, jakie to mogło pociągnąć za sobą skutki na terenie Prus Zachodnich. Dlatego też Niemcy oficjalnie zaprotestowały przeciwko temu pomysłowi, proponując $\mathrm{w}$ zamian przetransportowanie jej drogą kolejową przez terytorium centralnych Niemiec. Używano też argumentu, że jej przejazd przez Pomorze Gdańskie może spowodować wybuch krwawych walk pomiędzy Polakami i Niemcami, a nawet konflikt w Europie Środkowej. Te argumenty przekonały aliantów, którzy 4 kwietnia 1919 r. na mocy decyzji Waffenstillstandskommission w Spa postanowili wysłać „hallerczyków” drogą lądową. Sytuacja ta przekreśliła możliwość zrealizowania planu powstania narodowego na Górnym Śląsku, Wielkopolsce, Pomorzu i w Prusach Wschodnich ${ }^{13}$.

Strona niemiecka zdawała sobie sprawę $\mathrm{z}$ faktu dobrego zorganizowania miejscowych Polaków i starała się ograniczać rozwój i rolę rad ludowych wśród lokalnych społeczności. Odpowiedzią Niemców było także tworzenie własnych niemieckich rad ludowych. W Gdańsku powstała Niemiecka Rada Ludowa dla Prus Zachodnich, na gruncie lokalnym natomiast m.in. w Bydgoszczy, Toruniu, Chełmży i Gru-

\footnotetext{
${ }^{11}$ M. Wojciechowski, Pomorze $w$ dobie odbudowy państwowości polskiej 1918 1920, [w:] Powrót. Dokumentacja ustanowienia suwerenności polskiej na Pomorzu w latach 1918-1920, wyboru dokonali J. Bełkot i M. Wojciechowski, Torun 1988, s. 12.

${ }_{12}$ J. Wojtowicz, op. cit., s. 152-153; M. Wojciechowski, Dzieje Chetmży, s. 156.

${ }^{13}$ M. Wojciechowski, Powrót Pomorza, s. 88-89.
} 
dziądzu $^{14}$. W Chełmży powstała ona 29 grudnia 1918 r., a na jej czele stanął sekretarz Magistratu K. Kriebel. W styczniu 1919 r. niemieckie rady $\mathrm{z}$ tej części prowincji weszły w skład kierowanej przez Georga Cleinowa Deutsche Vereinigung z siedzibą w Bydgoszczy ${ }^{15}$.

Rozpoczęto także proces obsadzania wojskiem niemieckim powiatów, w których dominowała ludność polska. Powołano również do życia paramilitarną organizację ochotniczą o nazwie Grenzschutz Ost. W dniu 6 stycznia 1919 r. w Czersku doszło do starć tej formacji z tamtejszą polską ludnością, która wychodziła z kościoła po uroczystej mszy z okazji Święta Trzech Króli. Podczas zamieszek zginęło kilka osób, a kolejnych kilkanaście zostało aresztowanych ${ }^{16}$.

Z kolei w pamięci mieszkańców Chełmży zapadła akcja Grenzschutzu Ost pod dowództwem Gerharda Rossbacha ${ }^{17}$, który 28 stycznia 1919 r. wydał rozkaz ostrzelania Chełmży ogniem artyleryjskim. Wojsko niemieckie rozpoczęło zdobywanie miasta. Na miejscu lub od ran zmarło sześcioro jego mieszkańców: Jan Szczypiorski, Antoni Kiełbasiewicz, Franciszek Rosiński, Weronika Żurawska, Edward Zieliński, Alfons Wiliński i dwunastoletni Kazimierz Lewandowski. Chełmża została zajęta i spacyfikowana ${ }^{18}$.

Bez wątpienia czynnikiem, który wpływał na zaognienie miejscowych stosunków polsko-niemieckich, stał się wybuch 27 grudnia $1918 \mathrm{r}$. powstania $\mathrm{w}$ stolicy Wielkopolski. Walki nie dotarły wprawdzie do terenu prowincji zachodniopruskiej, ale w rękach polskich znalazł się np. Inowrocław położony $35 \mathrm{~km}$ na południowy zachód od Torunia, a także Mogilno oraz Nakło znajdujące się przy ważnej linii kolejowej relacji Berlin-Królewiec.

Rozejm w Trewirze podpisany 16 lutego 1919 r., przedłużający zawieszenie działań zbrojnych na froncie zachodnim, usankcjonował ten stan rzeczy. Zajęty przez powstańców obszar pozostawał wprawdzie formalnie nadal częścią Republiki Weimarskiej (Niemiec), ale

\footnotetext{
${ }^{14}$ J. Wojtowicz, op. cit., s. 152.

${ }^{15}$ M. Wojciechowski, Dzieje Chetmży, s. 156.

${ }^{16}$ J. Wojtowicz, op. cit., s. 153.

${ }^{17}$ Ibid., s. 152.

${ }^{18}$ M. Wojciechowski, Dzieje Chetmży, s. 159.
} 
w praktyce władzę na kontrolowanej przez siły powstańcze większości prowincji przejęły polskie kręgi polityczne związane z Naczelną Radą Ludową w Poznaniu. W jej zarządzie wiceprezesem był pochodzący z Pomorza ks. dr Antoni Wolszlegier. W ramach Naczelnej Rady Ludowej istniał także, składający się z sześciu osób, Komisariat, w którym zasiadał również delegat reprezentujący Pomorze - dr Stefan Łaszewski z Grudziądza. Stało się to po tym, gdy władze niemieckie wiosną 1919 r. rozpoczęły działania represyjne. Zaplanowały m.in. aresztowanie Stefana Łaszewskiego pod zarzutem zdrady stanu. Zmusiło go to do opuszczenia miasta i udania się do Poznania. Od tego momentu Podkomisariat działał faktycznie w Poznaniu. W Gdańsku, w sposób nieformalny, jego pracami zajmował się Józef Wybicki. W dniu 17 maja 1919 r. Niemcy zakazali ostatecznie działalności Podkomisariatu Naczelnej Rady Ludowej w Gdańsku. Rozwiązali także Towarzystwa Wojackie „Jedność” w Chojnicach, Świeciu, Suszu i Lubawie oraz struktury „Sokoła” w Brusach, Gdańsku i Grudziądzu. Silnej cenzurze, zakazom ukazywania się lub konfiskatom nakładu poddano polską prasę: „Gazetę Gdańską”, „Gazetę Grudziądzką”, „Głos Lubawski”, „Przyjaciela Ludu” i „Polnische Warte”.

Jednym z ostatnich działań Niemców, mającym na celu przeciwdziałanie oddaniu spornego terytorium, stał się postulat przeprowadzenia na nim plebiscytu. Mieszkańcy Prus Zachodnich mieli w nim odpowiedzieć na pytanie: do jakiego kraju chcą należeć. Przygotowania rozpoczęto po niemieckiej przegranej w prowincji poznańskiej. W styczniu 1919 r. na stanowisko Komisarza Rzeszy dla Spraw Wschodu powołano Augusta Winniga, który w maju 1919 r. ustanowił swojego reprezentanta dla Prus Zachodnich i rejencji bydgoskiej - lokalnego polityka SPD Juliusa Gehla ${ }^{20}$. Dalszym krokiem ze strony niemieckiej stało się powołanie w Berlinie Wydziału Parlamentarnego Północ. Miał to być rodzaj lokalnego ciała przedstawicielskiego, które ostatecznie otrzymało nazwę Parlament Niemieckiego Wschodu. Głównym jego zadaniem było przekonanie aliantów do wydania decyzji dotyczącej przeprowadzenia plebiscytu na obszarze Prus Wschodnich i Zachodnich

\footnotetext{
${ }^{19}$ M. Wojciechowski, Powrót Pomorza, s. 117-119.

${ }^{20}$ Ibid., s. 115.
} 
oraz rejencji bydgoskiej ${ }^{21}$. Biorąc pod uwagę ilościową przewagę ludności niemieckiej i występującą, zapewne znaczną, grupę ludności indyferentnej i labilnej narodowościowo - mającej raczej charakter ludności pogranicza - postulat ten mógł nieść groźne dla Polski konsekwencje. Idea przeprowadzenia plebiscytu została jednak, głównie dzięki stanowisku Francji, odrzucona.

Traktat kończący wojnę z Niemcami został ostatecznie podpisany 28 czerwca 1919 r. Na jego mocy państwo niemieckie miało oddać większość, uzyskanych w wyniku rozbiorów Rzeczypospolitej Obojga Narodów, obszarów Wielkopolski i Pomorza Gdańskiego. W przypadku tego ostatniego do Polski włączono 62\% obszaru Prus Zachodnich $\left(15864,5 \mathrm{~km}^{2}\right)$, m.in. ziemie chełmińską, michałowską i lubawską. W Polsce znalazły się również tereny Kaszub (powiaty pucki, wejherowski, kościerski, kartuski i chojnicki), Kociewia (powiaty starogardzki i tczewski). Po niemieckiej stronie granicy pozostała jednak m.in. spora grupa ludności polskiej zamieszkująca powiat złotowski. Z kolei tereny na południe od Elbląga, tzw. Powiśle z powiatami kwidzyńskim, sztumskim i malborskim, zostały poddane decyzji plebiscytowej. Głosowanie w sprawie przynależności tego terenu odbyło się 11 lipca 1920 r. i zakończyło porażką strony polskiej. Ostatecznie do Rzeczypospolitej przyłączono jedynie pięć z sześciu gmin głosujących za Polską. Oprócz nich z okręgu kwidzyńskiego do województwa pomorskiego włączono port w Korzeniewie, most wraz z przyczółkiem mostowym w Opaleniu (przeniesiony w drugiej połowie lat 20. XX w. do Torunia) oraz dworzec kolejowy w Gardei ${ }^{22}$.

Gdańsk, jako stolica regionu, został wydzielony wraz z Sopotem i Żuławami i przekształcony w nowy organizm państwowy - Wolne Miasto Gdańsk. Jego polityka zagraniczna oraz system celny miały być powiązane z Rzecząpospolitą Polską, jednak w praktyce od samego początku władze Wolnego Miasta dążyły do osłabienia tych zależności i odbudowania bliskich relacji z Niemcami.

\footnotetext{
${ }^{21}$ Ibid., s. 115-116.

${ }^{22}$ Marienwerder Westpreussen. Aus dem leben einer deutschen Stadt an der unteren Weichsel, red. O. Gründer, F. Neumann, Celle 1983, s. 292-293; W. Wrzesiński, Plebiscyty na Warmii i Mazurach oraz na Powiślu w 1920 r., Olsztyn 1974, s. 279.
} 
Na włączonych do Polski terenach przeważali Polacy, zwłaszcza na obszarach wiejskich. Jedynie w powiecie sępoleńskim oraz znajdującej się na północ od Świecia tzw. Kosznajderii mieszkała na wsiach znaczna część ludności niemieckiej.

W sumie na przyznanych Polsce terenach mieszkały 964704 osoby, a w powiązanym z Polską Wolnym Mieście Gdańsku - 330630 osób. Stanowiło to około $75 \%$ mieszkańców dawnej prowincji Prusy Zachodnie ${ }^{23}$.

Decyzje polityczne podjęte w Paryżu, a usankcjonowane traktatem w Wersalu, trzeba było jeszcze wprowadzić w życie. Przekazanie w sposób pokojowy i uporządkowany wspomnianych terenów mogły zapewnić jedynie wspólne polsko-niemieckie przygotowania do tego aktu. Temu celowi służyło wiele spotkań między delegacjami obu państw, podczas których, w sposób szczegółowy, ustalono praktyczne aspekty zmiany przynależności państwowej terenów oraz ich mieszkańców. Posiedzenia komisji odbyły się m.in. w lipcu 1919 r. w Bydgoszczy, Gdańsku i Toruniu, a jednym z ich efektów stało się reaktywowanie działalności Podkomisariatu Naczelnej Rady Ludowej z siedzibą w Gdańsku. Ponadto podczas spotkania w Toruniu 16 lipca ustalono m.in. zakaz ataków prasowych, powołanie straży mieszkańców, możliwość pozostawienia niemieckich urzędników w polskiej administracji, kwestię służby wojskowej czy też dopuszczenie do niektórych niemieckich urzędów polskich mężów zaufania. Znaleźli się oni np. w Naddyrekcji Poczty, Dyrekcji Kolei, Wyższym Sądzie Krajowym czy przy rejencyjnych wydziałach szkolnych ${ }^{24}$.

W miesiącach letnich 1919 r. przyjęto, że przyszłe województwo pomorskie obejmować będzie wyłącznie obszary wchodzące dotychczas w skład Prus Zachodnich. Nie zdecydowano się wówczas na włączenie Kujaw Zachodnich z Bydgoszczą i Inowrocławiem czy też Kujaw Wschodnich i ziemi dobrzyńskiej. Nowym, z punktu widzenia tradycji historycznej, nabytkiem stało się natomiast mazurskie Działdowo, które przed rozbiorami nie było częścią Rzeczypospolitej. Drugim wątkiem, związanym z województwem, była kwestia jego stołecz-

\footnotetext{
${ }^{23}$ P. Kosiński, op. cit., s. 80

${ }^{24}$ Ibid., s. 84.
} 
ności. Pod uwagę brano położony tuż przy granicy z Wolnym Miastem Gdańsk Tczew, następnie Starogard, graniczący z Niemcami Grudziądz, mający być objęty plebiscytem Kwidzyn oraz Toruń. To ostatnie miasto położone było na południowym końcu województwa pomorskiego. Na jego korzyść przemawiały natomiast: duży odsetek ludności polskiej oraz liczne elity społeczne i polityczne istniejące od okresu zaborów. W Toruniu działało Towarzystwo Naukowe (założone w 1875 r.). Tu wydrukowano, po raz pierwszy na ziemiach polskich, w $1858 \mathrm{r}$. Pana Tadeusza. Toruń był także miastem, w którym można było umieścić duży garnizon wojskowy w twierdzy. Było też dobrze skomunikowane, a przez jego obszar przechodziły liczne drogi kolejowe. Ostatecznie to właśnie Toruń został wybrany na przyszłą stolicę województwa, co skutkowało m.in. tym, że już w październiku 1919 r. z Gdańska rozpoczęto przenoszenie agend Podkomisariatu Naczelnej Rady Ludowej. Z nich następnie 5 grudnia 1919 r. powołano do życia Urząd Wojewódzki Pomorski, mający swoją tymczasową siedzibę w Poznaniu, a docelowo w Toruniu. Pierwszym wojewodą władze polskie mianowały wspomnianego już Stefana Łaszewskiego.

Powrót Pomorza do Polski nie nastąpił szybko, co zaczęło wywoływać wśród mieszkańców, w miarę upływającego czasu, obawy co do jego realności. Spodziewano się bowiem szybkiej ratyfikacji dokumentu, a w niemieckim parlamencie procedura ta stale się przedłużała. Jednak 24 października 1919 r. podpisano w Berlinie „Porozumienie w sprawie wojskowego przekazania terenu Polsce”. Na jego podstawie miało się ono rozpocząć o 6 rano siódmego dnia po złożeniu dokumentów ratyfikacyjnych $\mathrm{w}$ Paryżu. Niemiecki parlament ratyfikował traktat wersalski dopiero 10 stycznia 1920 r., co pozwoliło 17 stycznia rozpocząć proces przejmowania przyznanego Polsce terytorium.

Władze polskie w Warszawie podjęły już wcześniej decyzję o utworzeniu Frontu Pomorskiego, którego dowódcą został generał broni Józef Haller. W skład wojsk Frontu weszły następujące jednostki Wojska Polskiego: 11. Dywizja Piechoty z Błękitnej Armii i 16. Dywizja Piechoty, zwana „Dywizją Pomorską”. Ta ostatnia gromadziła w swoich szeregach żołnierzy z ziem zaboru pruskiego, w tym z terenu Pomorza. 
Proces przejmowania Pomorza trwał do 10 lutego 1920 r. Podzielony został na dwie fazy: w pierwszej miano zająć Gniewkowo (17 stycznia, wraz z przygotowaniem się do zajęcia Torunia), Toruń (18 stycznia), Brodnicę, Nowe Miasto Lubawskie, Lubawę (17-19 stycznia), Wąbrzeźno i Bydgoszcz (20 stycznia), w dniach 20-22 stycznia pozostałą część Kujaw Zachodnich i obwodu nadnoteckiego, 21 stycznia Chełmżę, dzień później Chełmno, 23 stycznia Grudziądz i Sępólno. W ramach fazy drugiej zaplanowano obsadzenie Świecia, Nowego, Skórcza (25-28 stycznia), Starogardu i Chojnic (29 stycznia), Tczewa, Czerska, Tucholi, Kościerzyny (30 stycznia), Brus (31 stycznia 1 lutego) i najdalej na północ wysuniętych Wejherowa i Helu (1-4 lutego). Tego ostatniego, końcowego terminu, nie udało się dotrzymać, gdyż pojawiły się trudności z transportem kolejowym polskiego wojska przez obszar Wolnego Miasta Gdańska. Dopiero dzięki interwencji Wysokiego Komisarza Ligi Narodów Reginalda Towera zostało zawarte stosowne porozumienie, co pozwoliło zająć pozostały obszar do 10 lutego $1920 \mathrm{r}^{25}$

Formalne przekazanie Pomorza rozpoczęło się w Toruniu - stolicy województwa pomorskiego. Do miasta, od strony mostu kolejowodrogowego, 18 stycznia 1920 r. o godzinie 15.30 wkroczyły oddziały Dywizji Pomorskiej pod dowództwem płk. Stanisława Skrzyńskiego. Następnie od strony dworca Torun-Miasto przemaszerowały w kierunku rynku, gdzie nastąpiło oficjalne przekazanie miasta. Dokonał tego nadburmistrz Hasse na ręce dowódcy Dywizji Pomorskiej. Wojsko Polskie, w imieniu polskiej społeczności, przywitał natomiast prezes Toruńskiej Rady Ludowej Otton Steinborn. W imieniu rządu polskiego władzę cywilną nad całym terenem województwa przejął minister byłej Dzielnicy Pruskiej Władysław Seyda. Następnie oddał zarząd województwa Stefanowi Łaszewskiemu. Szczególną oprawę zyskało przybycie do miasta gen. Józefa Hallera. Dowódca Frontu Pomorskiego uczynił to 21 stycznia i rozpoczął swój pobyt od złożenia wieńca przed pomnikiem Mikołaja Kopernika. Wieńce złożyli również, przybyli wraz z nim, prezydent Warszawy Piotr Drzewiecki i przewodniczący tamtejszej Rady Miejskiej Ignacy Baliński.

${ }^{25}$ M. Wojciechowski, Powrót Pomorza, s. 198, 200. 
Pomorze powróciło do Polski, jak pokazała przyszłość, już na stałe. Karty historii się odwróciły i rozpoczął się proces pełnej polonizacji regionu, zakończony ostatecznie w 1945 r. powrotem Gdańska i pozostałych ziem pomorskich do Polski.

\section{Bibliografia}

Belzyt L., Sprachliche Minderheiten im preußischen Staat 1815-1914, Marburg 1998.

Dzieje Chetmna. Zarys monograficzny, red. M. Biskup, Warszawa-PoznanToruń 1987.

Kosiński P., Prusy Zachodnie 1914 - Pomorze 1920. Ludność regionu wobec przemian politycznych okresu I wojny światowej, Warszawa 2002.

Marienwerder Westpreussen. Aus dem leben einer deutschen Stadt an der unteren Weichsel, red. O. Gründer, F. Neumann, Celle 1983.

Szurło-Gorzelak M., Pomorski Urząd Wojewódzki. Jego powstanie, rozwój i chwila obecna, [w:] Księga pamiątkowa dziesięciolecia Pomorza, 19201930, red. M. Sydow, Torun 1930.

Wapiński R., Polska i małe ojczyzny Polaków, Wrocław-Warszawa-Kraków 1994.

Wojciechowski M., Powrót Pomorza do Polski 1918-1920, WarszawaPoznań-Torun 1981.

Wojciechowski M., Pomorze w dobie odbudowy państwowości polskiej 19181920, [w:] Powrót. Dokumentacja ustanowienia suwerenności polskiej na Pomorzu w latach 1918-1920, wyboru dokonali J. Bełkot i M. Wojciechowski, Torun 1988.

Wojciechowski M., Dzieje Chetmży w latach 1914-1920, [w:] Dzieje Chetm$\dot{z} y$, red. M. Wojciechowski, Chełmża 1994.

Wojtowicz J., Czasy zaboru, [w:] Województwo bydgoskie. Krajobraz. Dzieje. Kultura. Gospodarka, Poznań 1967, s. 150-151.

Wrzesiński W., Plebiscyty na Warmii i Mazurach oraz na Powiślu w 1920 r. Olsztyn 1974. 